\title{
Rozwój kompetencji proinnowacyjnych u uczniów - przykład niemieckich szkół podstawowych i ponadpodstawowych
}

\author{
DOI: 10.47050/65591876.80-99 \\ Piotr Trąpczyński
}

\begin{abstract}
Głównym celem tego rozdziału jest analiza zagadnienia pedagogiki w zakresie przedsiębiorczości w Niemczech na poziomie szkolnictwa podstawowego i średniego oraz zidentyfikowanie dobrych praktyk w rozwijaniu proinnowacyjnych kompetencji u uczniów. W rozdziale wykorzystano przegląd międzynarodowej literatury związanej z edukacją przedsiębiorczą, a następnie w szczególności źródła pierwotne dotyczące rozwiązań stosowanych w Niemczech. Przedstawiona analiza akcentuje znaczenie wzajemnego oddziaływania rozwiązań na różnych poziomach: poziom państwa (lub, w przypadku zdecentralizowanych systemów edukacyjnych, takich jak niemiecki, poziom regionalny), poziom inicjatywy szkolnej, a także indywidualny poziom nauczycieli odpowiedzialnych za wdrażanie metod nauczania przedsiębiorczości.
\end{abstract}

\section{Słowa kluczowe:}

kompetencje proinnowacyjne

kreatywność

edukacja w zakresie przedsiębiorczości

szkolnictwo podstawowe i średnie

Niemcy 


\section{Development of pro-innovative \\ competences among pupils - an example of German primary and secondary schools}

DOI: 10.47050/65591876.80-99

Piotr Trąpczyński

The main objective of this chapter is to analyse the case of entrepreneurial pedagogy in Germany at the level of primary and secondary education and to identify good practices in the development of pro-innovative competences of pupils. The chapter uses a review of literature on entrepreneurial education, and particularly primary sources related to the solutions implemented in Germany. The analysis highlights the relevance of an interplay of solutions at different levels: the level of the state (or, in the case of decentralised educational systems like the German one, at the regional level), the level of school initiative, as well as the individual level of educators who are in charge of implementing entrepreneurial teaching methods.

\section{Keywords:}

pro-innovative competences

creativity

entrepreneurship education

primary and secondary education

Germany 


\section{Wprowadzenie}

Rozwój kompetencji proinnowacyjnych jest postrzegany jako jedno z najważniejszych wyzwań współczesnych systemów edukacyjnych i szerzej pojętego rozwoju społeczno-gospodarczego (Marques, Albuquerque 2012; Tasnim, Yahya 2013). W rzeczywistości edukacja z zakresu przedsiębiorczości kształtuje postawy i intencje przedsiębiorcze, a także zdolności innowacyjne młodego pokolenia (Wach 2015, 2013; Moreno, Wach 2014).

Choć edukacja w zakresie innowacyjności i szerzej pojętej przedsiębiorczości w światowej literaturze znajduje się obecnie u szczytu swej popularności, w Polsce jest to wciąż relatywnie nowy i zyskujący na znaczeniu temat, w coraz większym stopniu podejmowany przez naukowców różnych dyscyplin. W ostatniej dekadzie XX W. w literaturze przedmiotu toczyła się debata na temat tego, czy można nauczyć się przedsiębiorczości i innowacyjności (Wach 2016a, 2016b). Postawy przedsiębiorcze, w tym kreatywność w biznesie, to ważne atrybuty pożądane na rynku pracy, zatem edukacja uniwersytecka powinna wyposażyć absolwentów nie tylko w odpowiednią wiedzę i umiejętności, ale także w pożądane postawy przedsiębiorcze (Wach 2014a, 2014b). W tym duchu edukacja w zakresie przedsiębiorczości jest znacznie szersza niż sama edukacja biznesowa lub ekonomiczna.

Mimo że od dawna zwracano uwagę na istotne znaczenie edukacji akademickiej w kształtowaniu postaw przedsiębiorczych i zdolności proinnowacyjnych (Kwieciński, Młodzińska-Granek 2014; Wach 2016b, 2002), możliwości i ograniczenia wdrażania pedagogiki z zakresu zdolności innowacyjnych na poziomie edukacji szkolnej były analizowane w mniejszym stopniu. Ponieważ nie istnieje zgodność co do tego, czy przedsiębiorczość jest cechą wrodzoną, czy nabytą (Henry, Hill, Leitch 2005), zasadne wydaje się jak najwcześniejsze rozwinięcie postaw przedsiębiorczych, w szczególności kreatywności, tak potrzebnej we własnej działalności gospodarczej.

Niniejsze opracowanie przedstawia analizę zagadnienia prowadzenia edukacji na rzecz rozwoju kompetencji proinnowacyjnych w Niemczech na poziomie szkolnictwa podstawowego i średniego. Poświęcenie uwagi temu systemowi kształcenia wynika z konkretnych przesłanek. W grudniu 2016 r. Organizacja Współpracy Gospodarczej i Rozwoju (OECD) opublikowała raport Programme for Internatio- 
nal Student Assessment ${ }^{1}$ (PISA) - Program Międzynarodowej Oceny Umiejętności Uczniów za 2015 r. Zgodnie z tym raportem Niemcy należą do pierwszej dziesiątki krajów europejskich w badaniu wyników uczniów, ale nadal wykazują większe niż przeciętnie luki w osiągnięciach w niektórych dziedzinach (OECD 2016). Z przykładu Niemiec można zatem czerpać wiedzę nie tylko na temat dobrych praktyk dla rozwoju kompetencji proinnowacyjnych, ale także niedoskonałości związanych z wdrażaniem przyjętych rozwiązań systemowych i możliwych podejść do radzenia sobie z nimi.

W pierwszej części niniejszego rozdziału wyjaśniono pojęcie pedagogiki na rzecz przedsiębiorczości i dokonano przeglądu współczesnych koncepcji dydaktycznych, w szczególności nauczania zorientowanego na proces. Następnie przedstawiono przypadek niemiecki w celu przeanalizowania sposobu, w jaki można wdrożyć pedagogikę z zakresu rozwoju zdolności innowacyjnych i kreatywności na różnych, powiązanych ze sobą poziomach. W sekcji podsumowującej omówiono czynniki warunkujące powodzenie wdrożenia takiego podejścia.

\section{Przegląd literatury}

Innowacyjność jest uznawana za jeden z ważnych czynników wpływających na procesy rozwoju społeczno-gospodarczego (Daszkiewicz 2014; Wach 2016b). Celem systemu edukacji na wszystkich poziomach kształcenia powinno być przede wszystkim kształtowanie kompetencji proinnowacyjnych u młodzieży i studentów (Urbaniec 2014; Wach 2016b, 2013; Wach, Wojciechowski 2016). Ma to bowiem wpływ na ich późniejszy, pełny i satysfakcjonujący udział w życiu społeczno-gospodarczym (Wach 2015; Rachwał, Wach 2016). Znaczenie gospodarcze małych i średnich przedsiębiorstw spowodowało zmiany w procesach umiędzynarodowienia przedsiębiorstw i globalizacji gospodarki światowej, sprawiając, że przedsiębiorczość i kreatywność w biznesie należą do kluczowych czynników rozwoju gospodarczego. Należy to brać pod uwagę, projektując systemy kształcenia (Othman, Nasrudin 2016).

Tak zwana pedagogika przedsiębiorczości zajmuje się metodami nauczania, które zachęcają do kształtowania postaw przedsiębiorczych (Wach 2014a). W przeciwieństwie do konwencjonalnego podejścia do 
procesu uczenia się, które polega na uzyskiwaniu wiedzy od nauczyciela (Vermunt, Verschaffel 2000), koncepcja ta zakłada wzajemne przekazywanie sobie kompetencji i umiejętności. Wówczas rola ucznia przestaje być bierna, zastępuje ją bowiem uczenie się przez działanie (zob. rysunek 1). W przeciwieństwie do zdobywania wiedzy ze źródeł pisanych poprzez czytanie, metoda ta obejmuje edukację poprzez dialog i bezpośrednią wymianę informacji. Przedsiębiorcze ujęcie kształcenia się zakłada, zamiast uczenia się zgodnie z instrukcjami nauczyciela jako głównego eksperta, samodzielność ucznia i korzystanie z porad nauczyciela. Podobnie, w przeciwieństwie do uczenia się w dobrze zorganizowanym środowisku według z góry ustalonego harmonogramu, rozwijanie umiejętności w zakresie przedsiębiorczości powinno odbywać się w elastycznym, nieformalnym środowisku (Gibb 1993).

Rysunek 1. Koncepcja przedsiębiorczej edukacji

PRZEDSIĘBIORCZOŚć
INDYWIDUALNA
(kreatywność, inicjatywność)
kompetencje
interpersonalne

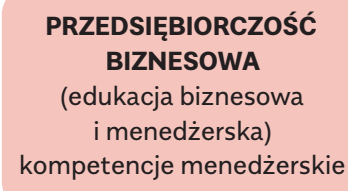

(edukacja biznesowa

i menedżerska)

kompetencje menedżerskie

\section{PRZEDSIĘBIORCZOŚĆ}

W GOSPODARCE

(edukacja ekonomiczna

i finansowa)

kompetencje ekonomiczne

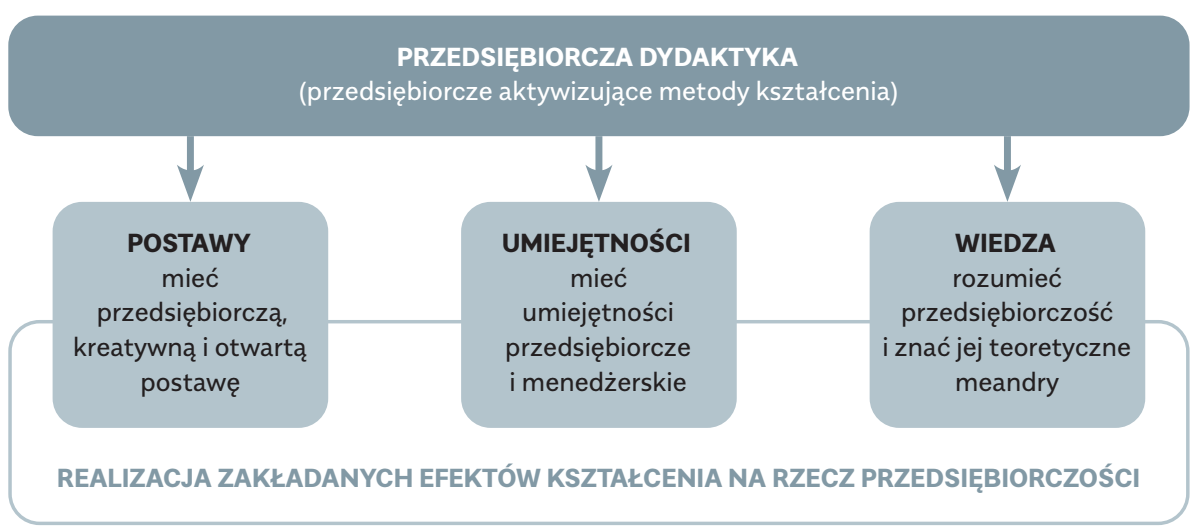

Źródło: Wach 2016a, s. 17.

Na zasadność koncepcji przedsiębiorczej edukacji wskazują wyniki istniejących badań. Wskazują one bowiem, że wiedza zdobyta przez 
jej aktywne rozwijanie jest bardziej dostępna i użyteczna niż ta przyjmowana biernie. W związku z tym w ostatnich latach coraz częściej zwracano uwagę na znaczenie podejścia do nauczania zorientowanego na proces (Abdous 2011; Brown 2010; Chen, Chen, Chen 2014; Vacek 2011). Wzajemne uznanie i dobre relacje nauczycieli i uczniów są podstawą dydaktyki zorientowanej na proces (Apelojg 2016).

Dydaktyka ukierunkowana na proces skupia się na procesie kształcenia się uczniów zgodnie ze wspólnie zdefiniowanymi celami uczenia się. W dydaktyce ukierunkowanej na proces chętnie podejmuje się wyzwania związane z ograniczeniami w przyswajaniu wiedzy i pomaga się wykorzystać je w rozwoju w procesie zdobywania wiedzy. Uczący się są zatem świadomi, że popełnianie błędów jest częścią procesu uczenia się. Są oni w dużym stopniu odpowiedzialni za osiąganie swoich celów indywidualnych i radzenie sobie z wyzwaniami. $Z$ drugiej strony nauczyciele są $w$ tym procesie moderatorami, starają się nieustannie rozwijać własną koncepcję nauczania. Postrzeganie uczenia się jako procesu implikuje ciągłe kwestionowanie postępów uczniów i nauczycieli oraz wyznaczanie nowych celów rozwoju. Dydaktyka zorientowana na proces zapewnia zarazem wiele przestrzeni zarówno nauczycielom, jak i uczniom, aby mogli osiągać cele kształcenia.

Można przyjąć, że istnieją trzy podstawowe, wzajemnie powiązane formy uczenia się, którymi są świadome i nieświadome doświadczenie, imitacja oraz metoda prób i błędów (Apelojg 2016). Te trzy podstawowe tryby uczenia się dają odpowiednie wskazówki dotyczące procesu uczenia się. Po pierwsze, nauczyciele i uczniowie, oprócz świadomych doświadczeń edukacyjnych, mają również wiele doświadczeń nieświadomych. Po drugie, rola negatywnych doświadczeń edukacyjnych powinna być traktowana poważnie i stale uwzględniana w projektowaniu procesu kształcenia, ponieważ pomyłki stanowią wartościowe źródło wiedzy. Po trzecie, należy pamiętać, że uczniowie muszą jednocześnie doświadczyć sukcesu, aby mieć właściwą motywację do nauki (Zob. szerzej Łuczak-Trąpczyńska, Trąpczyński 2017).

\section{Studium przypadku: rozwój kompetencji proinnowacyjnych w Niemczech Kontekst badania}

W tabeli 1 przedstawiono listę kompetencji, które zostały zidentyfikowane na podstawie wywiadów z ekspertami uczestniczącymi w przepro- 
wadzeniu ekspertyzy "Szkoła dla innowatora" na zlecenie Ministerstwa Przedsiębiorczości i Technologii w 2017 r. oraz na podstawie kwerendy źródłowej. Należy zauważyć, że sama koncepcja „kompetencji proinnowacyjnych" nie jest powszechnie znana. Eksperci z Danii, Finlandii, Irlandii, Izraela, Japonii, Korei Południowej, Niemiec, USA i Wielkiej Brytanii, którzy uczestniczyli w realizacji niniejszego badania, często nie znali takiej koncepcji (Fazlagić 2018b). Jest ona zatem swego rodzaju novum, jeśli chodzi o dokumenty strategiczne dotyczące systemów edukacji. Przedstawiona w tabeli 1. lista stanowi kompromis między koniecznością syntezy zagadnień z analizowanego obszaru a rozległością badanego zagadnienia.

Tabela 1. Konceptualizacja kompetencji proinnowacyjnych

\section{UMIEJĘTNOŚCI POZNAWCZE}

1) Ciekawość i odkrywanie nowych możliwości - uczenie, jak zainteresować innych swoją osobą, i patrzenia w przyszłość; nagradzanie uczniów za zadawanie pytań; nauczanie, jak nie być zadowolonym z pierwszej opcji, zachęcanie do ciekawości i chęci szukania kolejnych możliwości. Uczenie, jak eksperymentować i być otwartym na empiryczną weryfikację swoich założeń.

2) Powstawanie pomysłów - uczenie, jak tworzyć i rozwijać pomysły własne oraz innych. Kompetencja silnie związana z kreatywnością w rozumieniu psychologii.

3) Rozwiązywanie problemów - zdolność do rozwiązywania problemów i przezwyciężania przeszkód. Kompetencji tej towarzyszy postawa proaktywna wobec trudności i wyzwań.

4) Samodzielność myślenia - przełamywanie modeli mentalnych; uczenie, że „nie wszystko złoto, co się świeci"; myślenie niestandardowe, nawet jeśli czasami oznacza niezgodność z powszechną opinią. Identyfikowanie przydatnych źródeł informacji oraz zbieranie i selekcjonowanie tylko tych informacji, które są niezbędne/wartościowe.

5) Myślenie dywergencyjne - nauczanie, jak zmieniać perspektywę i patrzeć na problem z innego punktu widzenia.

6) Kadrowanie problemów - operacjonalizacja abstrakcyjnych obiektów/zjawisk/idei; nauczanie, jak dla abstrakcyjnego i mglistego pojęcia stworzyć wymierne ramy pojęciowe, punkty odniesienia, parametry pomiarowe itp.

7) Praca nad wieloma problemami w tym samym czasie - nauczanie, jak pracować jednocześnie nad kilkoma projektami lub wstępnymi pomysłami bez przedwczesnego wybierania "właściwych" i eliminowania pozostałych. Kompetencja związana z tolerancją dla wieloznaczności (ambiguity).

8) Umiejętność uczenia się - kompetencja związana z umiejętnością uczenia się, a także analizowania, identyfikowania pozytywnych i negatywnych zdarzeń i ich przyczyn; zdolność do doskonalenia i usprawniania istniejących rozwiązań.

UMIEJĘTNOŚCI BEHAWIORALNE

9) Odwaga i podejmowanie ryzyka - demonstrowanie odwagi i niezależności myślenia, a także zdolności do doceniania wysiłków innych osób. U liderów kompetencja ta wiąże się z nauczaniem odwagi i stawiania czoła wyzwaniom, nagradzaniem „tych, którzy się odważą”. Rozwój tej kompetencji wiąże się z nauczaniem, że niezgadzanie się z autorytetem jest w niektórych sytuacjach pozytywną postawą. Chodzi o kształtowanie u młodzieży zdolności do podejmowania ryzyka w życiu i akceptowania porażek. 
10) Wizualizacja problemu i rozwijanie wyobraźni poprzez przydatne metafory - żyjemy w świecie nadmiaru informacji. Wizualizacja informacji staje się podstawową metodą przezwyciężenia „przeładowania informacyjnego”. Uczenie, jak wyjaśniać i nadawać sens światu dzięki komunikacji pośredniej, w tym metaforom, rysunkom, schematom, jest bardzo ważne.

11) Podejmowanie decyzji - branie odpowiedzialności za decyzje, terminowość; branie na siebie odpowiedzialności i zarządzanie ryzykiem.

12) Liderowanie - przewodzenie sobie samemu i innym. Wskazywanie znaczenia dobrego przywództwa dla powodzenia realizacji planu; podejmowanie inicjatywy.

13) Opóźniona lub odroczona gratyfikacja - zdolność do oparcia się pokusie natychmiastowej nagrody i oczekiwanie na późniejsze wynagrodzenie.

14) Zarządzanie zmianą i improwizacja - uczenie, jak improwizować, pracować bez agendy lub poza nią, próbowanie osiągania rezultatów bez wcześniejszych przygotowań, mobilizowanie zasobów ad hoc, uczenie, jak radzić sobie z niepewnością i zmianami, przygotowywanie uczniów na sytuacje, w których kilka interpretacji jest wiarygodnych; ocena sił, które popychają lub hamują pomysł w danej sytuacji.

15) Wytrwałość - znaczenie niepoddawania się; usilne próbowanie, sprawdzanie wszystkich możliwości, niezniechęcanie się zbyt łatwo.

16) Rozwijanie zainteresowań i nauczanie, że posiadanie hobby jest zasobem - Nagradzanie uczniów za rozwijanie zainteresowań; zachęcanie ich do działań nieobjętych programem nauczania.

17) Współpraca - uczenie jak osiągać synergię, wykorzystywać zasoby i umiejętności innych ludzi na zasadach win-win; nauczanie jak słuchać sugestii innych i próbować nowych pomysłów.

18) Rozwijanie orientacji na przyszłość - nauka o zaletach spoglądania na przyszłe możliwości; ocena przyszłych kierunków i ryzyka na podstawie obecnych i przyszłych silnych stron, słabych stron, szans i zagrożeń.

UMIEJETTNOŚCI FUNKCJONALNE

19) Podstawowe umiejętności - pisanie, czytanie, liczenie.

UMIEJĘTNOŚCI TECHNICZNE

20) Podstawowe umiejętności - obsługa programów komputerowych, zrozumienie i wykorzystywanie technologii do doskonalenia procesów w pracy.

Źródło: Fazlagić 2018b, s. 21-23.

Wykorzystując operacjonalizację pojęcia kompetencji proinnowacyjnych przedstawioną powyżej jako kwestionariusz wywiadów półustrukturyzowanych, przeprowadzono łącznie 27 wywiadów z trzema grupami interesariuszy: nauczycielami na poziomie szkolnictwa podstawowego i średniego, urzędnikami w wybranych ministerstwach kultury i oświaty (Kultusministerien) oraz naukowcami specjalizującymi się w edukacji, pedagogice i metodach nauczania. Wyróżniono przy tym rozwiązania zlokalizowane na trzech poziomach: 
$\rightarrow$ poziomie federalnym oraz krajów związkowych,

$\rightarrow$ poziomie instytucji edukacyjnych,

$\rightarrow$ poziomie praktyki nauczania.

Niemiecki system szkolnictwa podstawowego i średniego składa się z czterech głównych obszarów studiów: obszaru elementarnego, obszaru pierwszego, pierwszej fazy drugiego obszaru i drugiej fazy drugiego obszaru (Besonderheiten... 2016). Każdy z nich obejmuje poszczególne rodzaje szkół, które różnią się znacząco w zależności od kraju związkowego. Konferencja Stała Ministerstw Kultury i Oświaty Krajów Związkowych Republiki Federalnej Niemiec (Die Ständige Konferenz der Kultusminister der Länder in der Bundesrepublik Deutschland) określa wytyczne i standardy edukacji, ale przepisy dotyczące kształcenia różnią się znacząco w szesnastu krajach związkowych, co skutkuje szesnastoma niekiedy znacząco rozbieżnymi systemami. Szkoły na ogół mają autonomię w kształtowaniu i wdrażaniu własnych programów nauczania, w których określają swoje priorytety tematyczne czy metodyczne (Deutscher Bildungsserver 2017). Ministerstwa kultury i oświaty opracowują wytyczne dotyczące polityki edukacyjnej, nauki i sztuki, wydają regulacje prawne i administracyjne, komunikują się z najwyższymi władzami federalnymi i kontrolują niższe władze, podległe korporacje, instytucje i fundacje. Aby pomóc ministerstwom, kraje związkowe ustanowiły własne instytuty szkolnictwa wyższego, edukacji i kształcenia zawodowego.

Należy również dodać, że odpowiedzialność za stworzenie katalogu dalszych kursów szkoleniowych spoczywa również na ministerstwach edukacji krajów związkowych. Poprzez sieć doradców zawodowych, którzy uczęszczają na zajęcia w szkołach i omawiają z nauczycielami potrzeby w zakresie edukacji, nauczyciele mają pośredni wpływ na rozwój katalogów kursów kształcenia ustawicznego.

\section{Rozwiązania na poziomie federalnym oraz krajów związkowych}

W toku badań zaobserwowano, że na poziomie federalnym i krajów związkowych obowiązują dobre praktyki kształtujące różne kompetencje proinnowacyjne (zob. tabela 1). I tak, ciekawość i odkrywanie nowych możliwości wynikają z wynajdowania nowych kontekstów i wyzwań. Stąd międzynarodowe programy dające możliwość nawiązania wielu 
kontaktów oraz wymiany międzynarodowej są szczególnie ważnym narzędziem w tym zakresie, wykorzystywanym również w Niemczech. Do programów tych można zaliczyć m.in. Erasmus czy konkurs dla uczniów Youth for Space Challenge - ODYSSEUS II (Bawarskie Ministerstwo Oświaty, Kultury, Nauki i Sztuki 2017f). Na poziomie krajów związkowych Federacji Niemieckiej można zidentyfikować inicjatywy mające na celu organizowanie wymiany międzynarodowej dla uczniów. Program stypendialny "ambasadorowie Bawarii" bawarskiego ministerstwa oświaty daje uczniom mającym 15-18 lat możliwość wyjazdów zagranicznych do wybranych krajów (Bawarskie Ministerstwo Oświaty, Kultury, Nauki i Sztuki 2017g). Ponadto, w ramach parlamentarnego programu patronażowego ze Stanami Zjednoczonymi, młodzież w wieku 15-17 lub młodzi pracujący w wieku 15-24 lat mogą ubiegać się o roczne stypendium na wymianę $w$ USA.

Warto zwrócić uwagę także na programy informacyjne dla uczniów w zakresie możliwości wyjazdów lub zwiększające ich świadomość na temat funkcjonowania integracji międzynarodowej. I tak, w ramach programu ConAct można uzyskać informacje w zakresie kontaktów między młodzieżą z Niemiec i lzraela, a także wsparcie w nawiązywaniu nowych relacji pod kątem wymiany młodzieży (ConAct 2017). Otwarte w 2001 r. centrum koordynacji programu rocznie wspiera ok. 300 projektów pozaszkolnych kształcenia i wymiany na poziomie finansowym i pedagogicznym. Inicjatywa "Europa kinderleicht" [Europa dziecinnie prosta] przygotowuje materiały informacyjne dla dzieci w wieku 9-12 lat na temat funkcjonowania Unii Europejskiej, przyczyn jej założenia oraz działalności na rzecz obywateli (Ministerstwo Szkolnictwa i Kształcenia Kraju Związkowego Nadrenia-Westfalia 2019).

Programy wspierające u młodzieży zdolność do formułowania pomysłów dotyczą różnych aktywności. Po pierwsze, w toku badań literaturowych zidentyfikowano konkursy wspierające przedsiębiorczość. Program Jugend gründet [Młodzież zakłada firmę] wspiera kreatywność i przedsiębiorcze myślenie u uczniów dziesiątej klasy, którzy nie rozpoczęli studiów ani nie ukończyli kształcenia zawodowego. Samodzielnie lub w zespołach sześcioosobowych uczniowie otrzymują możliwość przeżycia wirtualnego procesu zakładania firmy. Zespoły opracowują nowe strategie sprzedaży, plany finansowe, taktyki marketingowe czy innowacje produktowe (Bawarskie Ministerstwo Oświaty, Kultury, Nauki i Sztuki 2017a). 
W Niemczech działają także inicjatywy wspierające niezależne myślenie. Do tej kategorii można zaliczyć nagrody przyznawane przez poszczególne ministerstwa kultury i oświaty, np. Nagroda Klausa Hildebranda w Bawarii z zakresu wyróżniających się prac o tematyce ekonomicznej i finansowej na poziomie szkół ponadpodstawowych w roku szkolnym 2016/2017 (Bawarskie Ministerstwo Oświaty, Kultury, Nauki i Sztuki 2017d). W tym samym kraju związkowym funkcjonuje również program JUNIOR wspierający przedsiębiorczość w szkołach na terenie Bawarii. W jego ramach uczniowie zakładają własne przedsięwzięcie ograniczone czasowo na rok. Przez ten czas przejmują odpowiedzialność za powodzenie swojego przedsiębiorstwa, działającego podobnie do prawdziwej firmy (Bawarskie Ministerstwo Oświaty, Kultury, Nauki i Sztuki 2017b).

W toku przeprowadzonych badań literaturowych, uzupełnionych o rozmowy z ekspertami, można zidentyfikować różne inicjatywy na poziomie ministerstw oświaty, zmierzające do zmiany perspektywy w postrzeganiu uczniów. I tak, bawarski projekt Europa zwischen Tradition und Moderne [Europa między tradycją a nowoczesnością] zakłada pracę zespołów uczniów różnych szkół nad zadaniami z rozmaitych obszarów tematycznych i dziedzin sztuki. W ten sposób uczniowie w różnym wieku i z różnych typów szkół poznają ewolucję europejskiej tradycji i dziedzictwa kulturowego. Podobnie, zakończona już kampania Vielfalt als Chance [Różnorodność jako szansa] miała na celu zwiększenie świadomości przedsiębiorstw, administracji i innych instytucji w dziedzinie etnicznej i kulturowej różnorodności jako istotnego atutu gospodarki niemieckiej i czynnika sukcesu społecznego. Wreszcie, obiecującym projektem w zakresie rozwoju umiejętności przyjmowania odmiennych perspektyw jest międzynarodowa symulacja posiedzeń Organizacji Narodów Zjednoczonych, w której uczestniczą uczniowie szkół. Pracują oni nad uchwałami związanymi z różnymi istotnymi problemami społecznymi i gospodarczymi, szukając kompromisów między różnymi perspektywami.

Umiejętność uwzględniania i rozważania równorzędnych koncepcji jest w Niemczech również wspierana przez instytucje funkcjonujące ponad podziałami administracyjnymi. Adekwatnym przykładem jest tutaj projekt KIEWIS dla uczniów wszystkich krajów związkowych, prowadzony od 2007 r. przez organizację Wissensfabrik. W jego ramach w firmach odbywają się zajęcia, dzięki którym uczniowie mogą 
skonfrontować zdobytą wiedzę z procesami faktycznie zachodzącymi w praktyce gospodarczej. Dzięki temu odkrywają różne wzajemnie powiązane obszary funkcjonowania przedsiębiorstwa, które razem przyczyniają się do realizacji celów organizacji.

Podobnie, konkurs gry biznesowej „Play the Market" jest skierowany do uczniów od dziesiątej klasy, którzy mogą wykorzystać swoją wcześniejszą wiedzę do prowadzenia wirtualnego przedsiębiorstwa. Muszą podejmować decyzje w takich obszarach jak sprzedaż, kadry, finanse czy planowanie zaopatrzenia. Uczestniczące, trzyosobowe zespoły działają na różnych rynkach i bezpośrednio konkurują z innymi firmami.

$Z$ drugiej strony aktywność i podejmowanie ryzyka przez uczniów są wspierane przez takie organizacje jak fundacja Rock It Biz wspomagająca zakładanie firm przez uczniów. W trakcie realizacji projektów uczestnicy muszą rozwinąć pomysł na biznes, pozyskać finansowanie, stworzyć produkt i przemyśleć sposoby jego wprowadzenia na rynek. Dzięki temu młodzież odkrywa swoje predyspozycje i upodobania w ramach pracy zespołowej. Ma przy tym możliwość spotkania się z przedsiębiorcami. Podobną rolę odgrywa inicjatywa ifex Ministerstwa Finansów i Gospodarki kraju związkowego Badenia-Wirtembergia realizowana we współpracy z lokalnym ministerstwem oświaty. Celem podejmowanych działań jest promowanie przedsiębiorczości wśród uczniów i wskazanie jej jako alternatywy dla innych ścieżek zawodowych.

Wykształceniu u uczniów umiejętności podejmowania decyzji sprzyjają inicjatywy na styku praktyki gospodarczej i szkolnictwa. Przykładowo, business@school jest inicjatywą firmy doradczej Boston Consulting Group, w ramach której zespoły uczniowskie zajmują się analizą działalności biznesowej dużych, a także średnich i małych firm. $Z$ tym podstawowym rozumieniem działania modeli biznesowych słuchacze podejmują decyzje na temat kształtowania własnego planu biznesowego i przedstawiają przed szerszą publicznością swoje pomysły na działalność przedsiębiorczą. Podobnie, od 2012 r. funkcjonuje program firm uczniowskich JUNIOR skierowany do uczniów szkół poziomu ponadpodstawowego. W ramach programu uczniowie przez cały rok prowadzą uczniowską firmę, rozdzielając między siebie funkcje typowe dla struktury faktycznej firmy. Sami muszą definiować kluczowe etapy jej działalności, takie jak koncepcja biznesu, założenie, kapitał zakładowy czy sprzedaż produktów. 
Kompetencje proinnowacyjne są ponadto rozwijane na poziomie instytucjonalnym za sprawą inicjatyw na poziomie krajów związkowych i ponad ich granicami. Jednym z programów realizowanych w szkołach w Bawarii jest odpowiedzialne prowadzenie banku przez zespoły uczniowskie pod egidą Federalnego Związku Banków Niemieckich (Bawarskie Ministerstwo Oświaty, Kultury, Nauki i Sztuki, 2017c). Podobnie, projekt Gründerkids [Dzieci-Założyciele] wspiera rozwijanie zdolności przywódczych u uczniów uczestniczących w programach zakładania firm uczniowskich, dzięki organizacji indywidualnych konsultacji, szkoleń i spotkań networkingowych w całym kraju.

\section{Rozwiązania na poziomie instytucji edukacyjnych}

Na szczeblu szkolnym poza wymianami uczniowskimi na uwagę zasługują projekty, mające na celu rozwijanie ciekawości u uczniów i identyfikowanie nowych możliwości, dotyczące np. odkrywania korzeni rodzinnych. Przykładowo w Szkole Podstawowej Siegerland w dzielnicy Berlin-Spandau, w kraju związkowym Berlin od 10 lat prowadzi się projekty eTwinning, w ramach których uczniowie zajmują się poszukiwaniem swoich korzeni rodzinnych w innych krajach Europy. Projekty te zostały wyróżnione europejskimi nagrodami i znakami jakości. Oprócz rozbudzania ciekawości, rozwijają one również znajomość języków obcych. Jednocześnie projekty pozwalają na pogłębianie umiejętności wykorzystywania nowoczesnych technologii i technik poszukiwania informacji (Konferencja Ministerstw Szkolnictwa 2019).

Umiejętność formułowania pomysłów przez uczniów na poziomie organizacji pracy własnej może być w szkołach rozwijana podczas aktywności praktycznych przebiegających poza głównym nurtem nauczania. I tak, w Centrum Szkolnym Wilhelm-Raabe w Eschershausen (kraj związkowy Dolna Saksonia) w 2015 r. rozpoczęto budowę drewnianego budynku obok szkoły we współpracy z partnerami spoza szkoły. Praca przy budowie budynku miała służyć rozwijaniu przedsiębiorczości u uczniów. Dzięki podziałowi obowiązków przy budowie było możliwe rozwinięcie u nich poczucia odpowiedzialności, a także podejmowania inicjatywy i kreatywności. Realizacja własnych pomysłów wymagała również zaangażowania różnych innych osób (np. personelu technicznego) i tym samym wspierała interdyscyplinarność przedsięwzięcia.

Ponadto, w Niemczech duże znaczenie w szkołach mają tzw. wspólnoty pracy (Arbeitsgemeinschaften). Przykładowo, w szkole podstawo- 
wej w Oberstimm od roku akademickiego 2012/2013 zespół uczniów pod okiem nauczycielki prowadził raz w tygodniu badania własne pod hasłem "po drodze we wszechświecie". Jego wyniki uczniowie przedstawili Berndowi Siblerowi, sekretarzowi stanu ds. kultury, w trakcie jego wizyty w szkole wraz z m.in. planetami wykonanymi z papier mâché i tablicami informacyjnymi czy symulację światła księżycowego. Prezentacja spotkała się z bardzo pozytywną opinią.

Niezależne myślenie może być kształtowane już na poziomie definiowania wewnętrznych celów w programach nauczania w szkołach. I tak, w 2000 r. w Szkole Podstawowej Thomas-Mann-Grundschule (Berlin) wprowadzono wewnętrzny wykaz kompetencji w celu rozwijania u uczniów w trakcie sześcioletniego okresu nauki zdolności do samodzielnego uczenia się i pracy. Do tych celów, wyrażonych w programie nauczania szkoły, należą w szczególności rozwój wiedzy fachowej, kompetencji społecznych i medialnych. Podstawą pracy w grupach o mieszanych klasach 0-2 oraz 3-6 w 2000 r. zespół nauczycieli opracował wspólny program metodyczny. Dla przykładu, celem na koniec czwartej klasy jest samodzielne określenie kolejności zadań we własnym planie tygodnia. Uczniowie wybierają zadania do indywidualnego opracowania, przez co uczą się niezależnego myślenia i planowania swoich działań (Czerwanski, Solzbacher 2004).

Umiejętności te są również rozwijane przez organizację pracy. Zyskującą na popularności koncepcją w Niemczech jest tzw. model Jenaplan, realizowany w szczególności w szkole Jenaplan w mieście Jena (Jenaplan-Schule Jena 2019). W ramach tej koncepcji uczniowie w różnym wieku uczą się we wspólnych grupach projektowych, rozwiązując problemy mimo różnic $w$ stanie wiedzy i dojrzałości. Nie tylko wśród uczniów, lecz również wśród nauczycieli nadrzędną zasadą jest słuchanie innych i wspólne wyciąganie wniosków z odmiennych zdań oraz uczenie się na błędach (Czerwanski, Solzbacher 2004).

Do rozwoju odważnej postawy przyczyniają się aktywności poza salą lekcyjną, sprzyjające rozwijaniu umiejętności brania odpowiedzialności za konkretne działania. I tak, w Centrum Szkolnym Wilhelm-Raabe-Schulzentrum Eschershausen (kraj związkowy Dolna Saksonia) funkcjonowała uczniowska firma zajmująca się produkcją miodu i wosku, która stawia na produkcję ekologiczną i funkcjonuje jak faktyczne przedsiębiorstwo. Uczniowie są odpowiedzialni m.in. za zarządzanie personelem czy gospodarowanie kapitałem (inwestycje, pożyczki, dywi- 
dendy itd.). Ponadto, istotną rolę odgrywają tzw. wspólnoty pracy. Przykładowo w Gerhart-Hauptmann-Schule Griesheim uczniowie rozwijają wyobraźnię i zdolności poznawcze w ramach wspólnoty pracy twórczej, w której wykwalifikowane osoby uczą wytwarzania wyrobów z wełny, pereł, gumek typu loom bands czy nici. Podobnie, we wspólnocie zajmującej się garncarstwem uczniowie z zastosowaniem nauczanych technik wdrażają własne koncepcje, które po ukończeniu stają się ich własnością (Gerhart-Hauptmann-Schule 2019).

Zdolność do samodzielnego podejmowania decyzji w szkołach niemieckich jest uwzględniana m.in. na poziomie kształtowania planu zajęć i realizacji dłuższych projektów. I tak, w ramach nowych metod nauczania w Szkole Podstawowej Thomas-Mann w Berlinie pozwolono uczniom podejmować decyzje w zakresie kształtowania własnego planu zajęć. Przykładowo uczniowie samodzielnie decydują w sprawie czasu niezbędnego do poświęcenia $\mathrm{w}$ danym tygodniu na prace $\mathrm{w}$ ramach projektu opracowywanego przez dłuższy czas i wyznaczają sobie terminy kontrolne w tym zakresie (Czerwanski, Solzbacher 2004).

Innym przykładem mogą być projekty realizowane przez szkoły ponadpodstawowe wraz z firmami, jak np. współpraca uczniów w Badenii-Wirtembergii i Margarete Steiff GmbH, w ramach której rozważano, czy firma ta powinna zainwestować w produkcję w Chinach (Kształcenie Ustawiczne Nauczycieli w Badenii-Wirtembergii 2019).

Ważnym elementem rozwijania kompetencji społecznych u uczniów tej szkoły jest przydzielanie tzw. urzędów klasowych, czyli stanowisk związanych z przejęciem odpowiedzialności za jasno zdefiniowane obszary funkcjonowania danej klasy. Uczniowie mogą ubiegać się o "ministerstwa" w ramach rady klasowej w drodze głosowania lub losowania, np. „ministerstwo komputerów"" oznacza odpowiedzialność za codzienne uruchamianie sprzętu komputerowego i pilnowanie ich stanu, jak również pomoc techniczną dla innych uczniów. W wybranych przypadkach "minister komputerów" może wprowadzić dla określonych osób zakaz korzystania z komputera.

\section{Rozwiązania na poziomie praktyki nauczania}

Zdolność do formułowania własnych pomysłów na poziomie metod stosowanych w niemieckich szkołach wynika w pierwszej kolejności z częstego stosowania otwartych form prowadzania zajęć, zgodnie z koncepcją często powracającą w niemieckiej literaturze i publicystyce 
z zakresu reform pedagogicznych. Według tego podejścia uczniowie sami definiują swoje cele uczenia się, które chcą osiągnąć za pomocą pracy własnej. Osoba ucząca się ponosi odpowiedzialność za wybór form swojej pracy i treści, a także za planowanie różnych aktywności. Nauczyciel jest przy tym towarzyszem i doradcą. Tym samym zaciera się typowa szkolna hierarchia. Wszystkie zajęcia powinny odnosić się do zainteresowań i zdolności uczących się. Celem swobodnego uczenia się jest bowiem samodzielna nauka i wsparcie relacji społecznych. Uczący się sami znajdują optymalne sposoby nauki (Methodenpool Uni-Koeln 2019a).

Koncepcja otwartych zajęć zakłada połączenie własnej pracy uczniów, pracy według planu tygodniowego, jak również pracy projektowej. Wykorzystanie wielu z tych metod jest cechą otwartego podejścia do zajęć nastawionego na przybliżanie uczniom różnych sposobów rozwiązywania problemów. Koncepcja zajęć zorientowanych na problem zakłada, że nauczyciele i uczniowie wspólnie stawiają pytanie, które stanowi punkt wyjścia dalszej analizy. Ponieważ uczniowie współuczestniczą w formułowaniu problemów badawczych, to również oni muszą wypracować sposoby ich rozwiązania (np. metody laboratoryjne w naukach przyrodniczych). Warto przy tym zaznaczyć, że rozwiązywanie problemów może odbywać się metodą prób i błędów, dzięki zmianie perspektywy, szukaniu analogii do wcześniej rozwiązanych problemów i stosowaniu już wypracowanych strategii czy wreszcie twórczemu podejściu do rozwiązywania problemów (Spörhase-Eichmann 2004).

Innym przykładem metod nauczania i oceny rozwijających samodzielne myślenie jest praca projektowa, w której uczestnicy muszą samodzielnie wypracować narzędzia analityczne, np. zaprojektować ankietę przekazywaną następnie innym uczniom lub pracownikom szkoły. Opracowanie ankiety wymaga określenia celów i zgromadzenia zasobów, by je zrealizować, np. wiedzy z zakresu tworzenia ankiet oraz opracowania wyników (Müller 2006).

Wybór odpowiednich struktur myślowych i poznawczych dla zrozumienia złożonych treści jest istotną umiejętnością, która nie jest powszechnie rozwijana w szkołach, istnieją jednak praktyki mające na celu jej kształtowanie. Należy do nich nauczanie poznawcze (Cognitive Apprenticeship), w którym dąży się do praktycznego pokazania uczniom korzyści płynących z uczenia się, również w zdobywaniu wykształcenia teoretycznego. W tym podejściu, zaczerpniętym z dydaktyki konstruk- 
tywistycznej, rywalizujące ze sobą zespoły uczniowskie poznają np. znaczenie produkcji seryjnej. Analizują ją na podstawie konkretnych "produktów" (np. domków z kartonu), równocześnie mając za zadanie wytworzenie jak największej liczby domków według wzorca. Zespoły musiały same wypracować metodologię „produkcji”, obejmującą różne jej etapy, ich kolejność i powiązania (Methodenpool Uni-Koeln 2019b).

W toku przeprowadzonych badań zidentyfikowano stosowane w Niemczech metody wspierające umiejętność podejmowania decyzji. Praca grupowa, dzieląca się na fazę przygotowania, realizacji, prezentacji i ewaluacji, daje możliwość opracowania zwłaszcza nowych tematów dla uczniów. Dzięki nim muszą oni samodzielnie pogłębić wiedzę w zakresie danej dziedziny, podejmując wspólnie decyzje dotyczące kluczowych zagadnień swojego opracowania. Istotna jest przy tym rola nauczyciela w wyjaśnianiu uczniom reguł skutecznej pracy zespołowej. Metodą uzupełniającą pracę grupową jest metoda moderacji, która stanowi wsparcie w fazach kreatywnych pracy grupowej. Moderatorem decydującym o kierunku prac może być zarówno nauczyciel, jak i wybrany uczeń.

W ramach pracy projektowej uczniowie prowadzą działania zorientowane na cel, a zatem na wynik, które wiążą się z odpowiedzialnością za osiągnięcie danych założeń postawionych w projekcie. Zdefiniowanie sposobu terminowego osiągania danego celu (np. artykuł do gazetki uczniowskiej, raport, sztuka teatralna, piosenka czy prezentacja), w tym organizacja pracy, struktura projektu, podział obowiązków, należą do uczniów (Bauer 2003).

W ramach przybliżania uczniom wyzwań związanych z zagadnieniami zarządzania ludźmi i przywództwa często stosowaną praktyką jest uczenie się poprzez nauczanie. Uczniowie w ramach pracy $w$ grupach lub pracy przed zajęciami przejmują funkcję nauczycieli, którzy mają za zadanie wyjaśniać pozostałej części grupy dotąd przyswojone treści w wybrany przez siebie sposób oraz zgodnie ze swoim stanem wiedzy odpowiedzieć na pytania zespołu. Nauczyciel odgrywa w tym procesie jedynie rolę obserwatora, który nie interweniuje, o ile nie jest to konieczne (Martin 2010).

Podobną rolę odgrywa coraz częściej spotykane w Niemczech sprawowanie funkcji w klasie, jak np. rzecznik klasy czy rzecznik uczniów, które wiążą się z reprezentowaniem interesów danych klas przed radą pedagogiczną czy kierownictwem szkoły (Ustawa o szkolnictwie w Ber- 
linie 2019). Innowacyjną metodą nauczania zyskującą na popularności w Niemczech są symulacje dydaktyczne, w szczególności gry biznesowe. Przykładem może być trzydniowa symulacja na temat polityki komunalnej opracowana przez fundację Friedrich-Ebert-Stiftung i mająca formę hybrydową. Łączy ona symulację i pracę projektową w jednej ze szkół zawodowych o profilu ekonomicznym w Norymberdze, w grupie dwóch klas bankowych liczącej 48 uczniów. Sama praca projektowa była prowadzona przez 31 uczniów, podzielonych na grupy robocze do spraw materiału zdjęciowego, materiału filmowego, strony internetowej, zespołu redakcyjnego, grupy ewaluacyjnej i zespołu organizacyjnego (Kührt 2011).

\section{Podsumowanie i rekomendacje}

$\mathrm{Na}$ podstawie przeglądu literatury i analizy niemieckiego systemu edukacyjnego można stwierdzić, że w Niemczech rośnie tendencja do powracania do otwartej formy nauczania. Polega ona na tym, że to sami uczniowie określają swoje cele uczenia się, które chcą osiągnąć w ramach pracy własnej, realizowanej w sposób samodzielny i z dużą swobodą. Można zauważyć, że instrumenty wspierające rozwój kompetencji proinnowacyjnych już na poziomie szkolnictwa podstawowego i średniego są zapewniane przez państwo. Dzieje się tak za sprawą jego wytycznych i programów, a także instytucji edukacyjnych, które biorą odpowiedzialność za zapewnienie jakości edukacyjnej, jak również samych nauczycieli, upowszechniających najnowsze metody dydaktyczne.

Aby praktykować prawdziwie przedsiębiorczą filozofię nauczania, nauczyciele powinni stosować metody zachęcające uczniów do otwartości i innowacyjności w rozwiązywaniu problemów. W toku przeprowadzonych badań literaturowych i w rozmowach z nauczycielami stwierdzono natomiast, że wzbudzanie ciekawości nie jest nadal postrzegane jako istotna cecha nauczyciela, ponieważ nieoczekiwane pytania uczniów burzą rytm prowadzonych zajęć, a odpowiadanie na kolejne pytania wymaga czasu i rezygnacji z przekazania pierwotnie zamierzonych treści. W opinii nauczycieli uczniowie o odmiennych poglądach są z reguły postrzegani jako utrudniający nauczycielom prowadzenie zajęć. Z drugiej strony, zależy to jednak od specyfiki dyscypliny i przedmiotu. Przykładowo, w naukach ścisłych zachęca się do odważnego formułowania pomysłów już w ramach studiów pedagogicznych. Zgodnie z koncepcją dydaktyki zorientowanej na proces, 
popełnianie błędów jest motorem zarówno uczenia się, jak i samego nauczania. Jednak w Niemczech w trakcie hospitacji zajęć i praktyk, a także podczas aplikowania na stanowisko nauczyciela, więcej uwagi poświęca się samym błędom niż tolerancji dla nich, zgodnie z zasadą, że nauczyciel nie popełnia błędów.

W ramach niektórych kursów dokształcających wspiera się rozwijanie u nauczycieli zdolności do podejmowania decyzji w złożonych sytuacjach, jednak nie jest to zagadnienie dominujące w studiach przygotowujących do tego zawodu. W opinii nauczycieli umiejętność ta wiąże się jednak ze zdolnością do samodzielnego myślenia i rozwiązywania problemów, którą muszą posiąść sami i przekazywać ją uczniom. Ukończenie danego programu czy kursu dokształcającego nie wiąże się z podwyżką wynagrodzenia. Podwyżki są przewidziane przy zmianie grupy wynagrodzeniowej, ta z kolei zależy od statusu nauczyciela (czy jest urzędnikiem państwowym, czy osobą zatrudnioną), od specyfiki przedmiotu, rodzaju szkoły itd. Awans jest uzależniony nie tylko od stażu zawodowego, ale w dużej mierze również od zaangażowania w pracę organizacyjną lub dodatkowe aktywności w szkole.

Metody nauczania, a zarazem ewaluacji uczniów, wspierające otwarte i elastyczne myślenie coraz częściej bazują na studiach przypadku, podobnie jak w szkolnictwie wyższym. Dzięki tej formie kształcenia uczniowie zdobywają umiejętność samodzielnego rozwiązywania problemów. W Niemczech coraz częściej stosuje się metody uczenia się kooperacyjnego, rozwijające u uczniów zdolność do współpracy. Innowacyjną metodą nauczania zyskującą na popularności w Niemczech są również symulacje dydaktyczne, w szczególności gry biznesowe. Rozwój proinnowacyjnych umiejętności u uczniów wymaga odwołania się do pasji i zainteresowań uczniów. W toku przeprowadzonych studiów literaturowych stwierdzono jednak, że niewiele stosowanych metod nauczania w bezpośredni sposób rozwija zainteresowania uczniów. Bazując jednak na doświadczeniu dydaktyków, można stwierdzić, że coraz częściej taką rolę przejmują wspólnoty pracy. Podobnie, nie zidentyfikowano metod nauczania mających na celu rozwijanie umiejętności generowania różnorodnych pomysłów. Opinie ekspertów współpracujących przy niniejszej analizie wskazują jako słabość niemieckiego systemu nauczania koncentrację zarówno nauczycieli, jak i uczniów na realizacji danego zadania i dotarciu do rozwiązania uznanego za wzorcowe. 
Należy wreszcie zwrócić uwagę na to, że choć takie metody jak burza mózgów czy reguła odwrócenia są wykorzystywane coraz częściej, ich nadal ograniczona częstotliwość wynika również z faktu, że nauczyciele są zbyt świadomi poprawnych rozwiązań, co wywiera wpływ na sposób dochodzenia do odpowiedzi uznawanych za słuszne. Przez to proces formułowania przez uczniów pomysłów własnych nie jest w pełni swobodny. Ponadto same metody oceniania studentów są silnie zorientowane na rezultat, stąd z założenia nie wspierają samodzielnego myślenia. Zarówno w pracy indywidualnej, jak i grupowej uczniowie nie mogą zawsze myśleć liniowo, w rozumieniu sekwencji kroków opisanych według danego schematu, ponieważ w rzeczywistości praca nad danym zadaniem nie przebiega podręcznikowo. Tymczasem w niemieckich szkołach dominuje podejście zorientowane na wynik, zarówno na poziomie metod nauczania, jak i samych metod ewaluacji, co nie wspiera wytrwałości i pomysłowości w pokonywaniu trudności. Przez ciągłe ćwiczenie rozwiązywania problemów uczniowie muszą mierzyć się z nowymi wyzwaniami, jednak rolą nauczyciela jest rozwijanie u uczniów wewnętrznej motywacji do nauki, ponieważ to z niej wynika cierpliwość w pokonywaniu trudności. Przedstawione w tym rozdziale dobre praktyki stosowane $w$ Niemczech, a także opisane deficyty i bariery mogą stanowić inspirację dla krajów reformujących swoje szkolnictwo, w tym Polski. 